\title{
The Political Economy of the State and Human Rights Violations: A Case Study of the Nigerian State Under the Goodluck Jonathan Administration (2010 - 2015)
}

Olulana Olubankole Daniel

Postgraduate Student Department of Political Science

Faculty of Social Sciences University of Lagos Akoka, Yaba, Lagos, Nigeria

Doi: 10.19044/esj.2017.v13n28p182 URL:http://dx.doi.org/10.19044/esj.2017.v13n28p182

\begin{abstract}
In spite of the significant efforts and influence elicited by relevant actors and mechanisms poised playing a watchdog and/or regulatory role over the states activities for an enforcement of human rights protection, the state has been observably seen to continue to record human rights violations across various countries of the world. The case is particularly more sordid for countries of the global South integrated into an international political economy structure that engenders continue far reaching relations of exploitive dominance by states of the global North and their corresponding Dominant Class. This paper examines the outlook of the state's record of human rights violations under the Goodluck Jonathan Administration to understand if this pattern still holds sway. It also seeks to explain, with the aid of an eclectic theoretical framework constituting a mix of the Marxist and Neo-Liberal theory within the Political economy Approach, whether or not the state may continue to record human rights violations given its nature and character. The study discovered the foregoing statement to be in the affirmative and underscored the relevance of such an understanding in informing the need for the continuing enforcement efforts and influence exerted by the relevant actors and mechanisms for the protection of human rights by states. The study also recommends the need for the adjustment of the international political economy structural outlook to one that is void of an exploitative dominance of the states of the global North as well as the need for Welfarist and other relevant policies central to securing the human rights of the citizenry at a reasonable minimum to be formulated in Nigeria. The role and vibrant activities of the relevant actors and mechanisms is underscored as one central to birthing this reality as was seen in the way they galvanized public popular action in the elections that saw the voting out of the incumbent Ruling Class and its long-standing power holding party in
\end{abstract}


order to birth for the desired leadership of the state that will birth forth the desired reality.

Keywords: Class, Bourgeosie, Proletariat, Masses, Dialectics, Violations

\section{Conceptual Clarification}

\section{Human Rights}

The continuing interest in human rights is an indication of the high premium placed by governmental and non-governmental actors and individuals on an idea whose origin can, arguably, be traced to antiquity...there is a tendency to arrogate to the West the origin of the idea of human rights... (however) communities have existed throughout the world since antiquity in which elements of what we now designate as human rights were recognised and safeguarded by systems of laws and institutions (Jinadu Adele, 1982). The idea of Human Rights is quite simple. It is that human beings have certain rights simply by virtue of being human beings. These rights are of the essence of being human and a necessary condition of self-realisation. Because of their singular importance, individuals are entitled to, indeed required to claim them and society is enjoined, better yet, obliged to allow them. Otherwise, the quality of life is seriously compromised. Presumably (Ake Claude, 1989). From the perspective of intellectual history or the history of ideas, the development of the idea of human rights is bound up with the debate and controversy surrounding the doctrines of natural law and natural rights from which it is in a sense derivative...the dominant justificatory philosophical theory of human rights since the late eighteenth century, particularly in the Anglo-Saxon world, was that of Locke which posited the civil and political rights to life, liberty and property as the natural rights of the individual (Adele Jinadu, 1982). The Russian revolution however brought a wider definition to the idea of human rights which saw a merger of the Lockean liberal, individualist bourgeois theory of rights embraced by the dominant bourgeois class in the West with that of the Rousseauist and Marxist conception of rights which has its emphasis on social, economic, and by implication, cultural rights hitherto rejected by the bourgeois dominant class in the West. Locke's theory, which entailed a characteristic of resistance as well as that of limited government, provided the rationalisation if not a justification for a revolutionary break with the past for the American and French revolutionaries. Thus, in line with Adele Jinadu's (1982) position, "The American Declaration of Independence, the Virginia Bill of Rights (1776), the French Declaration of Rights of Man and the Citizen (1789) and the American Bill of Rights bear the Lockean influence. Constitution makers in countries of Europe, the Americas, Asia and Africa have also embraced this enduring legacy of the American and 
French revolutions and examples in adopting bills of rights and/or entrenching such bills in their constitutions."

On the international political landscape, as a result of the atrocities and gross violations in the immediate pre-world war II period, the United Nations Charter was drawn up in San Francisco in 1945 and made the promotion and enforcement of human rights its major concern. Subsequently, the Commission on Human Rights established by the Economic and Social Council, an organ of the UN, submitted a Universal Declaration of Human Rights which was passed by the General Assembly on 10 December 1948. This was followed by several regional human rights covenants and charters such as the European Convention on Human Rights, Permanent Arab Commission on Human Rights, and the African Charter on Human Rights. The Universal Declaration of Human Rights and the several regional human rights conventions and charters explicitly reflect a reference to the promotion of social and economic as well as political and civil rights; and place an emphasis on economic and socio-cultural rights as necessary pre-conditions for the qualitative expression of civil and political rights.

All human rights, according to the Final Declaration of the World Conference on Human Rights in Vienna (1993), must be treated by the international community globally in a fair and equal manner, on the same footing, and with the same emphasis (Peter R. Baehr, 1999). The African Charter on human is also explicit in this regard, and it more importantly emphasizes the overall implication of the outlook of socioeconomic rights to the protection/violation of civil and political rights as well, as it notes in its Preamble thus, "... Convinced that it is henceforth essential to pay a particular attention to the right to development and that civil and political rights cannot be dissociated from economic, social and cultural rights in their conception as well as universality and that the satisfaction of economic, social and cultural rights is a guarantee for the enjoyment of civil and political rights;"

\section{Political economy}

Political economy in its historical and theoretical context was the name of the discipline in the social sciences today referred to as Economics. This change of nomenclature became notably defined in the 19th century. As Claude Ake (1989) notes, This was more than a change of nomenclature; it entailed some change in the techniques and methodology and some value commitments of the science, changes of a magnitude as to raise some doubts whether political economy and economics could properly be referred to as different names for the same social science." Dow (1990) as referred to by Bas De Gaay Fortman (2011) posits that, "Political economy is best defined as an approach to economics, which puts first priority on practical, and 
policy issues, and tailors theoretical and empirical work accordingly. The economy is regarded as being located in historical time, interacting with a political, social and natural environment. Within the system the agents change and interact in a manner, which cannot be described adequately by the assumptions of neoclassical theory." Marx...indeed...tended to treat political economy as the science for understanding society in its entirety (Ake Claude, 1989). It is an approach which seeks to study society with an emphasis on the socioeconomic sphere in society, the arising socioeconomic interaction and implications and contradictions that emanate from such among the elements in the social, political and economic context / environment in which the socioeconomic activities of production, distribution and consumption take place, as well as how the dialectical outlook of the foregoing is relevant/central to shaping the overall outlook of the society; towards socioeconomic and societal welfare/equilibruim and development.

In the approach's historical and theoretical conceptual context, there are a number of schools and their corresponding theories that have emerged namely, the Mercantilist Political Economy school - with proponents such as Niccolo Machiavelli, the Liberal Political Economy school - having proponents such as the Physiocrats, Adam Smith, David Ricardo, Thomas Malthus, etc., the Neo-Liberal Political Economy school - having proponents such as Maynard Keynes, and the Structuralist Political Economy school having proponents such as Karl Marx, Antonio Gramsci, Immanuel Wallerstein, Andre Gundre Frank, etc. For the purpose of this study a heavy drawing on the Marxism Political Economy theory, which is one of the theories under the Structuralist Political Economy school, will be made coupled with an eclectic mix of a relatively small measure of such drawing on the Neo-Liberal Political Economy school as well. The choice of this mode of analysis may be apt with a consideration of the veritable empirical reality of the relevance of the Marxist explanation of the historical materialism of social formations; how the dialectics of the social relations that exist in the socioeconomic sphere - where man's material conditions central to his survival are to be legitimately secured - in society have been central to determining the social, political and economic outlook/ arrangement in society in every historical epoch of unfolding human history; even till contemporary times today. Equally, the relevance of a small measure of the tenets of the Neo-Liberal Political Economy school being added to the eclectic Political Economy theoretical framework adopted for this study is traceable to the psycho-social reality that it may suffice to say that Capitalism has appeared in empirically observable terms to, in addition to a fair mix of Welfarism, be in tandem with human nature and his social arrangement (that is, society) and has unlike Socialism survived and 
subsisted regardless of the threatening phases it has been confronted with in history, compared to Socialism. Observably, states that have embraced the practice of welfarism providing their citizenry with the minimum economic value necessary to meet their basic needs and have a reasonable extra-added measure to enjoy themselves have in spite of the far larger fraction of the wealth still being enjoyed by the Dominant Class seem to enjoy a state of social equilibrium. With the Soviet Union going defunct as well as the gettisoning of a perfect outlook of socialist ethos by nations such as Cuba and China among others, Socialism seems to have failed to meet the mark of a pragmatically possible sustainable reality/ socioeconomic and social system.

The Marxian political economy theory underscores the centrality of material conditions and the dialectics of the social relations and contradictions that arises from the pursuit of creating and acquiring such in the socioeconomic sphere in society as the point of departure to studying, explaining, and understanding the overall outlook of society and all its spheres - social, political, cultural, and economic. The Neo-Liberal political economy school proposes a minimum of government intervention in the control of the economy (in the form of fiscal measures to address such issues as control of inflation, full employment, etc.), with the free market forces of Demand and Supply, competition and price mechanism being in predominant control of the economy and opines this as being relevant to achieve efficiency, economic development, and social equilibrium.

\section{The State}

The way men should organise themselves into an ordered collectivity has always been a puzzle and it has therefore occupied a central place in political philosophy since antiquity like the way it features in the writings of modern social and political theorists (Fadakinte, 2013). The political thinking and conception of what should be defined as the nature and character of the state has thus sequentially evolved certain intellectual rationalisations that range from the natural theory, the divine theory, the social contract theory, to the force theory.

First, the natural theory defines the state in philosophical terms, seen as an organic entity, an independent community, organised as government and governed and supreme within a defined geographical area (Fadakinte, 2013). It is a theory often regarded as organic analogy because the state is like a living body whose nature is like that of biology. The theory explains the state as society, organized as a sovereign political body, a natural phenomenon, superior to and more valuable than the individuals who are its citizens. The natural theory conceives of the state as an integrated organism, set above individuals, a whole, greater than its component parts (Goodwin, 
1982; Sabine and Thorson, 1973). However, the divine theory of state lays emphasis on the community and the ruler conceives of the ruler as God's chosen ones possessing the divine right to govern the community. The ruler and his decisions that informs the chosen structure put in place to govern and administer the affairs of the community is thus considered as the state. This was an historical epoch when monarch accorded such divine rights to govern and embody the state to themselves and enforced that members of their community see it as such. The social contract theory evolved a historical epoch of social formation that enthroned ethos of humanism over theocratic, metaphysical or nature-based evolutionary rationalisations or values. Thus, the social contract theory conceives of the state as one that evolved out of a mutual agreement between the ruler and the ruled, an agreement which entailed the obligations and roles of either party to one another. "Thus, the contract was established when the all-powerful or sovereign, i.e. the people made an agreement that created the state and gave the ruler of the state certain powers. In other words the social contract theory was based on the concept of popular sovereignty in which the ultimate source of the power of the state was the people (Baradat, 1984)." The contract theory was formulated to take care of the problems of authority and individual freedom in society which, as argued by Unger, are the master problems of politics (Unger, 1975). The force theory appears to be a doctrine that has the subtlety of two bull elephants engaged in mortal combat (Knuttila and Wendee, 2000). The force theory posits that the state evolved out the goal of a few to impose their will on the far larger majority in a society, and the state is thus an instrument to actualize and perpetuate such dominance. "There are two dimensions to the force theory. One dimension holds that force has to be applied to maintain stability while the other dimension holds that society is a battlefield between social classes and force is used by a dominant social class to hold other classes to submission (Fadakinte, 2013). To the Marxists, the state was not built on any contract neither can it be an organic unity but it is built on force and usurpation because society is an imbroglio of class conflict of which the state's very existence is symptomatic (Goodwin, 1982; Knuttila and Wendee, 2000). Ever since the coming into existence of the modern state in 1648, the state - in its nature and character - has observably reflected an evolutionary trend that empirically approximates the proposition of the force theory and the Marxist theory alike. Even in theindustrially advanced states of the global North the nature and character state continues to reflect traits that empirically make it virtually an instrument in the hands of the Dominant Class to perpetuate their exploitative dominance over the subjugated socio-economic Class (Bas De Gaay Fortman, 2011, Gary B. Madison, 1998, John Perkins, 2004); an exploitative dominance which holds significant implications for human rights violations. The minimum 
protection of the human rights of the citizenry put in place in various nations of the global North which in response to the series of uprisings and civic action undertaken by members of the subjugated Class against the farreaching effects of the exploitative dominance of the Dominant Class preserved and perpetuated by the State, which is popularly referred to as Welfarism/Welfarist policies, also led the Dominant Class of such nations of the global North to move such wanton and extreme apetite of theirs for exploitative dominance to the peoples of nations of the global South. As in Africa, many states of the global South today were constructed to fit their exploitative domination inclined interests as a perpetual possible continuum by the Dominant Class who wielded the power of such imperialist states of the global North. After the historical materialistic epoch of colonialism in which extreme exploitative activities were undertaken on nations of the global South to make up for what seemed lost in the various nations of the global North where the subjugated Class had pushed against far-reaching exploitation and corresponding human rights violations, the newly created nations of the global South were then forcefully integrated in an equally dysfunctional and exploitative international political economic structure that will make for the ever continuing exploitative domination of the nations and peoples of the global South by the Dominant Class and - its instrumental apparatus - the state of various nations various nations of the global North. This has put the several states of the global South in a consequent outlook that is characterized by a continuing record of far reaching human rights violations. The states take after the colonial states which forcefully imposed themselves over the people as the states are forced to be nothing but an instrument in the hands of the imperialist states of the global North since such countries and states of the global South have been forcefully integrated into an international political economic structure that perpetuates the exploitative dominance of the states of the nations of the global North and their corresponding socio-economic Class, the Dominant Class. The resultant effect is that several states of the global South pandering to the fancies of the states and Dominant Class of the global North get alienated from the society in the nations they govern, as the nature and character of the set engenders an evolution of a Comprador Bourgeosie Class who manage the affairs of the state in the exploitative interest of the states and Dominant Class of the global North and in their own exploitative interests as well. Surely, these contradictions are what make for the gloomy and terrible observable picture of human rights violations engaged in by the state in Nigeria, the countries of Africa, and several countries of the global South. The feature of poor governance and other traits of political misrule exhibited by several states of the global South, as is manifest in the Goodluck Jonathan administration, then make these states of the global South and their citizenry 
of the global South unable to push for an adjustment of the exploitative international political economy structure into which they have been forcefully integrated into which holds significant implications for human rights violations - which the state is now overtly or covertly helping such violations to fester on and on.

\section{The political economy of human rights}

(The) Political economy of human rights, then, is a way of looking behind systemic violations and structural non-implementation. Naturally, its primary contribution lies in the field of socioeconomic rights. Here the core focus is acquirement: why and how people succeed or fail in acquiring what they need for sustainable livelihoods. Yet, its significance is not restricted to economic, social and cultural rights. Lack of implementation of civil, political and cultural rights also has to be assessed in a politico-economic context. Often non-implementation of human rights is structural, related to what might be called a "justice gap" (Lederach, 1999; Fortman Bas De Gaay, 2011). In the light of the present truth embraced by the international community to measure (true) development from a human centred perspective - in line with the United Nations Human Development Index (HDI) published in its annual Human Development Report (HDR), the relevance of the study of human rights - through the analytical theoretical framework of the political economy approach - which is principally concerned with human dignity and human centred development cannot be over-emphasized. Human dignity... is to be seen as not so much an element of human rights but its core. Human dignity, in any case, is the core value to which the exercise of any human right must be tested (Fortman Bas De Gaay, 2011). In the discourse on the political economy of human rights, the state, among other actors in the political system, plays an invaluable role in shaping the outlook of human rights conditions in society.

\section{Analysis}

\section{The political economy of the state and human rights violations}

The political economy of the state and human rights violations seeks to examine the outlook of the state's violation of human rights using the political economy approach. In spite of several efforts made by the relevant actors and mechanisms at the global, regional, and domestic levels to stall the negative trend, the literature indicates that states have continued to be the greatest culprits of human rights violations (Human Rights Watch World Report, 2014, 2015, 2016, Fortman Bas de Gaay, 2011, Gary B. Madison, 1998, John Perkins, 2004). Yet, the relevant literature on this subject appear to emphasise an air of optimism on the possibility of stalling the menace of 
states' records of human rights violations in their laws, policies and practices.

To be sure, as the literature reveals, the relevant actors and mechanisms championing the campaign for an enforcement of the conformity of states to protect human rights in their laws, policies and practices have observably recorded measurably significant feats in progressively achieving this reality in the behaviour of states. However, in spite of the notable measure of success they can be seen to have achieved in this direction, states still continue to record human rights violations as well (sometimes even returning to violate human rights which they have hitherto protected as a result of the pressure elicited by the relevant actors and mechanisms against earlier violations of such rights).

Political economy as a theoretical approach or framework for analysis places primacy on the role of economic conditions and the social relations that arise from the outlook of such conditions as a point of departure for explaining, understanding and determining the overall outlook of the state and society. The Marxist theory, a theoretical framework within the Structuralist school of the political economy approach, systematically explains how the social relations and contradictions that arise from the structural outlook of economic conditions in society give rise to the formation of socio-economic Classes with the Dominant Class, the privileged economic Class, evolving a Ruling Class which manages the affairs of the state and the society at large in the interest of the Dominant Class. This explains why states can be seen to enact laws, formulate policies and embrace practices that appear to violate human rights; especially the human rights of the masses, the subjugated socio-economic Class.

Thus, the Marxist theory explains why economic policies, and other policies in general (significantly shaped by economic policies) as they affect the economy, of states can be empirically seen in the literature to reflect an outlook that perpetuates a pattern that holds concrete implications for the violations of human rights. The taxation policy of states, and their arbitrary differing rates from country to country, reflect the embrace of a pattern that will continue to engender economic inequality and all the evils of its implications for the gross violation of the human rights; especially those of the far larger fraction of their citizenry - the masses. States (of both the global North and South), usually seeking to protect the interest of the Dominant Class (of both the global North and South), can also be seen to not put up economic policies that curb the excesses of multinational companies and the far reaching implications of such excesses for the violation of human rights (Gary B. Madison, 1998, Jeremy Sarkin \& Mark Koenig, 2011, Denis G. Arnold, 2010, John Perkins, 2004). Many of such origin countries are experiencing increasing rates of unemployment, underemployment, and 
poverty as these multinationals, typically owned by members of the Dominant Class of these countries are relocating their businesses to countries where they can exploit cheap labour and other factors of production, low taxes, etc. only to sell such goods to citizens of the origin country as well to reap financial gains which will continually be taken out of such a country's economy (Fortman, Bas De Gaay, 2011, John Perkins, 2004).

\section{The Political Economy Of The State And Human Rights Violations In Nigeria}

The outlook is comparatively worse for several states of the global South and their citizenry. In the hot pursuit of their exploitative interest to extreme ends, states and the corresponding Dominant Class of the global super-power nations of the West have created an exploitative international political economy context into which they, through colonialism and neocolonial structures, have forcefully integrated the economies of the states of the global South for a perpetual ever worsening pattern of exploitation in ways which correspond to the evil of gross human rights violations of their citizenry (Fortman Bas de Gaay, 2011; Neil A. Englehart, 2009; John Perkins, 2004; Claude Ake, 1981, 1985; Fadakinte, 2013). The exploitative behaviour of these politico-economic super-power states and corresponding various Dominant Class of the global North also significantly shaped the nature and character of the states of the global South, in terms of states' violation of human rights, on their assumption of the status of independent nations.

Hence, this international political economy context in which the Nigerian state was created and continues to exist in has significantly shaped the nature and character of the state and its behaviour of the violation of human rights. The foregoing statement applies to both the colonial and postcolonial Nigerian state, even to the state under the Goodluck Jonathan administration as "...at independence Nigeria began to evolve a political class, a class that was made up of those who took over from the colonial state hierarchy. Members of the class were mere agents of western capital who came to power to execute policies that were necessarily geared towards promoting the interest of metropolitan bourgeoisie like the way the colonial state did." (Fadakinte, 2013)

The Nigerian post-colonial state immediately after independence lacked internal cohesion and, also, with no enduring institutions to form the basis of a stable regime. Consequently, factions had to struggle for power and whichever faction won power privatized the office. Those who won political power used it as a private tool. (Ake, 1988; Collier, 2010). With the lack of a virile economic Base, the state appeared to be the only other economic instrument to be coveted by the Dominant Class. The result of the 
undemocratic behaviour of the Nigerian Dominant Class and Ruling Class has given rise to the continuing manifestation of vices such as corruption, violence, and several other features of political misrule which have had far reaching implications for the human rights violations of the Nigerian citizenry. Subsequently, arbitrary dwindling and ever worsening conditions of unemployment and under-employment, pension schemes, and the social welfare infrastructure in general have become typical features of the Nigerian economy and society. The sordid state of the economy has made poverty a readily observable feature as well. As Claude Ake (1989) says, "I cannot help feeling that Africa is where the critical issues in human rights will be fought out and where the idea will finally be consummated or betrayed."

\section{The Political Economy Of The State And Human Rights Violations Under The Goodluck Jonathan Administration (2010 - 2015)}

The appointment of President Goodluck Jonathan into the office of the president of the federal republic of Nigeria commenced on 5 May 2010, following the demise of the incumbent president, President Umaru Musa Yar'Adua, owing to some natural causes. On his victory at the polls at the April 2011 presidential elections, President Goodluck Jonathan was sworn in as the President of the federal Republic of Nigeria, being the third president of Nigeria's fourth republic. In sum of the years of service of President Goodluck Jonathan first as acting president and then as president, he spent five years and twenty-five days officially leaving office on 29 May 2015.

Capturing power on the platform of the Peoples' Democratic Party (PDP) political party, the leading national Comprador Bourgeoisie party in Nigeria at the time which had hitherto successfully evolved all the past presidents of Nigeria's fourth republic prior to him, it is only understandable to notice that the ever worsening socioeconomic conditions manifest on Nigeria's socioeconomic landscape prior to the Goodluck Jonathan admninistration equally went from bad to worse under the Goodluck Jonathan administration. Of course, the contradictions that emerged on the socioeconomic landscape form the point of departure for understanding and explaining the overview of resultant contradictions in all the other spheres of societal concern as a whole which translates to grave state violations of the human rights of the citizenry. The Ruling Class of the day condoned an extreme measure of corruption of political and public office holders leaving the individuals in such roles to engage in extreme embezzlement and unbridled looting of the nation's revenue. In line with the foregoing the Human Rights Watch Report 2015 (Events of 2014) reported that, Corruption and weak governance undermine the enjoyment of basic human rights for many Nigerians who live in abject poverty. High unemployment 
rates - along with public sector corruption and insecurity-were major issues in the March national elections. Undoubtedly, as noted by the Human Rights Watch Report 2006 (Events for 2005), Widespread corruption leads directly to violations of social and economic rights and exacerbates other causes of violence and intercommunal tension.

The foregoing coupled with the already unpalatable reality of epileptic power supply, among other related factors, led to the loss of confidence of investors in the Nigerian economy. Of course, this perhaps explains why the rate of unemployment typically continued to arbitrarily dwindle yearly until it recorded a noticeable rise from 9.9\% in Q4 2014 to $10.4 \%$ in Q4 2015, as well as the rate of underemployment which equally witnessed a rise from $17.4 \%$ in Q4 2014 to $18.7 \%$ in Q4 2015, with poverty levels following a similar negative trend under the Goodluck Jonathan administration. The implication of the foregoing for the Proletariat class which makes up the Nigerian labour force is the inability to qualitatively secure their basic needs as well as those of their dependants such as food, clothing, shelter, healthcare, education, and savings for contingencies in the near and far future. With the breakdown of social security schemes such as pension for retirees, the burden of hitherto able-bodied members of the labour force who now constitute dependants on their children who are now members of the labour force - largely unemployed or underemployed makes matters worse. The unemployed fraction of the labour force even suffer a far more gross violation of their human rights when compared to their underemployed counterparts. Of course, since labour is what is to be exchanged for the material value vital for survival, the denial of such an opportunity where the needed legitimate exchange can take place, which is a paid employment, invariably equals the denial of -the means of-survival of the unemployed persons. Equally, it is in the material value received in exchange for labour that the potential for qualitative expression of human rights is contained; first the individual and those of his dependants' social and economic rights primarily, as well as their civil and political rights not less importantly. If an unemployed/underemployed parent cannot boast of funds sufficient to give his/her child a good quality of education, how will the child be able to offer a constructive critical political followership to the political leadership in society to keep it accountable and effective in the business of governance and administration of the common resources of the society for protection of the human rights of all in society? In fact, how can the nutritional, shelter, clothing and healthcare needs of the unemployed/underemployed youth and his/her dependant(s) be taken care of in the absence/ gross insufficiency of the needed economic resources? How can the unemployed/underemployed youth remain informed and up-to-date on the relevant items of information needed to make an informed decision on 
civil/political rights of his/her's such as who to vote for in the next election without a means of or a grossly insufficient one for paying the bills for power supply to watch television or surf the internet to follow the news in the comfort of his/her home? Can an unemployed/underemployed youth who has not been able to address his/her basic needs for survival - feeding, clothing, shelter, healthcare, etc. qualitatively express his human rights or be in the right frame of mind to contribute any meaningful intellectual or other beneficial substance to society whether in the social, economic or civil, or political sphere? The answer to all the above related rhetorical questions is undoubtedly in the negative.

The pursuit of alternative sources to survival then may well lead these especially largely unemployed/underemployed members of the Nigerian labour force to embrace other possible means of survival which may entail corruption and violence. The consequent emergence of insecurity issues and insurgent groups in the form of militant groups both in the Niger Delta and Northern Nigeria in the light of the foregoing is therefore not farfetched. In the Niger Delta for instance, the unsalvaged effects of oil drilling over the years have caused extensive environmental pollution; negatively affecting the waterways and soil in the farms of the inhabitants among manifest hazards thus threatening their means of livelihood as well as their health. According to the Human Rights Watch Reports 2012 (Events in 2011), Decades of oils spills - from multinational oil company operations, sabotage of pipelines, and bunkering (theft) of crude oil-and widespread gas flaring have left the Niger Delta heavily polluted. A UN report in August found that oil pollution in the Ogoniland region of Rivers State may require the world's largest clean up ever, at an initial cost of US\$1 billion, and take up to 30 years. The UN team found that oil contamination had migrated into the groundwater in at least eight spill sites that Shell-the largest oil company in Nigeria-had claimed they had remediated. Capturing the behaviour of the Nigerian state under the Goodluck Jonathan administration to the foregoing challenge and many more which had significant implications for the violation of the human rights of the citizenry, the Human Rights Watch Report 2012 (Events of 2011) noted that, Endemic corruption, poverty, poor governance, and unchecked police abuses have created an environment where militant groups thrive and find ready recruits in the vast cadre of Nigeria's unemployed youth.

The setting up of an amnesty programme by the Yar'Adua administration and the resultant effect of the reported reasonable level of calm that the oil facilities in the Niger Delta region enjoyed revealed the lamentable socioeconomic conditions of the inhabitants of the Niger Delta region and the centrality of material value in forestalling the illiegitimate endeavor the youths were forced to take to if the state exuded traits of good 
governance and the environmental pollution had been long cleaned up so that the predominantly youthful members of the militant groups could remain engaged in agricultural occupations or have found a paid employment in agricultural set-ups there in the Niger Delta where their labour may be legitimately exchanged for material value to meet their needs for survival. In confirmation of the foregoing position, the Human Rights Watch Report 2012 (Events in 2011) notes that, The 2009 amnesty-which saw a few thousand people, including top militant commanders, surrendering weapons in exchange for cash payments - has reduced attacks on oil facilities, but kidnappings, mostly of family members of wealthy Nigerians, continued in the Niger Delta and southeastern Nigeria. The government made little effort to address the environmental damage from oil pollution, state and local government corruption, and political sponsorship of armed groups, which drive and underlie violence and poverty in the oil-rich region.

The inability of the Nigerian state under the Goodluck Jonathan administration to address the latter aforementioned root causes of the menace of militant groups' activities in the Niger Delta region following the of the declaration of the federal government's declaration of the terminal date for the amnesty programme as 2015 led to the return of the hitherto unemployed youths to their earlier discovered means of livelihood - being their militant group activities. On the issue of unemployment and underemployment as national challenges in the Nigeria society, in developed nations of Europe and America, where the unemployment and underemployment rates are far lower than that of Nigeria, there is the infrastructural provision of a vibrant- welfare/social security system that caters for the basic needs of the unemployed as well as the underemployed members of the nation's labour force; and their dependants. There is however no such infrastructure -as well as the lack of a vibrantly functional one in the case of social security schemes (pension) for retirees and children- in Nigeria. The implication of this is that the qualitative expression of the social, economic, civil, and political rights of the far greater fraction of the citizenry is severely curtailed, being grossly violated by the poor governance of the ruling class and the corruption of the ruling class and the Comprado Bourgeoisie Class in general extremely embezzling and looting the nation's revenue which ought to be channeled to such ends. Of course, in line with the state under the Goodluck Jonathan administration living up to the faithful protection of the interests of the members of the socioeconomic class which evolved the ruling class steering the state's affairs, the administration protected Nigeria's political and economic elite as they perpetuated their corrupt and other illegimate deeds while repressing opposing views and criticism of such acts by the press and public. . To this end, the Human Rights Watch Report 2012, 2013, 2014 on Freedom of Expression and The Media unanimously note that, Civil 
society and the independent media openly criticize the government and its policies, allowing for robust public debate. Yet journalists are still subject to arrest and intimidation when reporting on issues implicating Nigeria's political and economic elite. The Human Rights Watch Report 2014 (Events of 2013) speaking on Government Corruption further notes that, In a major setback in ending impunity for corruption among political officeholders, President Goodluck Jonathan in March 2013 "pardoned" Diepreye Alamieyeseigha, a former governor of Bayelsa State, and the only governor to have served prison time in Nigeria for corruption. Of course, security forces followed suit in the path of the state's character of corruption and gross violation of human rights with impunity as the Human Rights Watch Report 2012 (Events of 2011) notes that "As in previous years, the undisciplined Nigeria Police Force was implicated in frequent human rights violations, including extrajudicial killings, torture, arbitrary arrests, and extortion-related abuses. The police routinely solicit bribes from victims to investigate crimes and from suspects to drop investigations." Equally as a Nigerian newspaper, Daily Post, reported in an interview President Buhari granted with Al Jazeera; talking about the probe of the National Security Adviser under the Goodluck Jonathan administration, NSA, Col. Ambo Dasuki (rtd) corrupt handling of funds allocated for purchasing the needed weapons for the Nigerian military in the fight against the insurgent group, Boko Haram, he said, ...the 'sharing' of funds was responsible for the boldness at which the Boko Haram sect operated in recent years.... This is why we are prosecuting those who shared monies meant to procure hardware and software for the military...with revelations coming out from the arms probe, you can imagine where Dasuki will end up.

The socioeconomic contradictions of gross corruption of political and public office holders, as well as of the security forces - as members of the Comprado Bourgeosie Class- under the Goodluck Jonathan administration led to the worsening situation of insecurity in Nigeria. The continuing attacks of the Boko Haram militia first in Northern and Central Nigeria, and then afterwards, to several other regions of the country, led to adverse socioeconomic effects for the country such as loss of livelihood by the inhabitants of unsettled areas of especially the states of Northern Nigeria where the insurgency group Boko Haram operated, claimed, and had their base. Of course, companies increasingly relocated from Northern and Central Nigeria, which appeared to be the most attacked areas by the insurgency group, resulting in a steady increase in the unemployment rate. The arising high level of corruption and gross misconduct as the later probe of a number of political and public office holders - as well as security forces - under the Goodluck Jonathan administration reveals, of persons such as the expetroleum minister, Diezani Alison-Madueke, the ex-finance minister ( who 
according to a CNN report made a refund of 90 billion dollars' worth of hitherto embezzled government funds which she had earlier denied embezzling ), Okonjo Iweala, etc. added with the already worsening socioeconomic indices of epileptic power supply, insecurity, etc. led to the loss of investors' confidence in the Nigerian economy. The contradictions in the overall socioeconomic outlook of the country led to the rising levels of unemployment, underemployment, poverty, etc. which equally reflects the gross violation of the human rights of the Nigerian citizenry with impunity.

According to the Human Rights Watch Report 2015 (Events of 2014), "In May, President Goodluck Jonathan told journalists that allegations of corruption against members of his cabinet were politically motivated and that most acts were no more than "common stealing." Nigeria's national revenue in the coffers of the Nigerian government meant to be used to better the lives of the Nigerian people who largely were either unemployed or underemployed members of the labour force having no legitimate stable means of income to meet their needs for survival vital to the qualitative expression of their human rights was for the most part largely looted by the Ruling Class Comprado Bourgeosie Class of the Nigerian citizenry.

The gross corruption and other poor governance traits of the state under the Goodluck Jonathan administration appeared to come to a point where the Nigerian populace could no longer take it anymore and for the first time in the political history of Nigeria voted out the incumbent president, who aspired for a second term, in the 2015 presidential elections in order to have a change of the political leadership of the Nigerian state.

\section{Conclusion}

The outlook of the political economy of the state under the Goodluck Jonathan administration appears to reflect a trend of the state's violation of human rights that has characterized the nature and character of the Nigerian state from its inception to the Goodluck Jonathan administration in spite of the efforts of relevant actors and mechanisms to discontinue this trend. Thus, the continuing manifest trend observable in the literature under the Goodluck Jonathan administration seems to prove that given the nature and character of the state, and the Nigerian state in this particular case, the state may always record violations of human rights. An understanding of the state being prone to such unpleasant traits may well help the relevant actors (civil society organisations, (international) governmental and non-governmental organisations, the electorate, etc.) to appreciate the significance of continuing alertness and being awake to their civic responsibility of keeping their watchdog role vibrant over the state and its affairs. Sure enough, as the Marxist theory proposes, the role of the relevant actors in pushing for an adjustment of the exploitative international political economy structure into 
which Nigeria, as well as several countries of Africa and the global South have been forcefully integrated into as well as causing the Nigerian state to conform to a behaviour that protects the human rights of its citizenry is invaluably central and cannot be over-emphasized.

Unlike the proposition of the classical Marxist theory, the state as Antonio Gramsci - the pioneer scholar of the Neo-Marxist theory observes, appears to have survived various contradictions in humanity's history that should have seen its whittling away. Against all odds, the state has continued to exist till date and does not reflect any manifest observable trait of whittling away anytime soon. The state - the world over, as the literature reveals have also continued to record human rights violations till date. However, states of the global North have through the elicitation of veritable pressure from relevant actors in society that play a watchdog and/or regulatory role over the state's activities, caused such states to embrace welfarist and several related policies that secure the basic human rights of the citizenry; though the far larger fraction of the wealth, privileges, and power in such countries of the global North still observably remains in the possession of the Dominant Class translating to some measure of human rights violations continuing still. In like manner, the possible minimum achievable as manifest under the Goodluck Jonathan administration, is that the relevant actors can with the galvanization of popular political support and actions of the citizenry cause the state to provide a minimum of welfare that secures the basic human rights of the citizenry in counties of the Africa and the global South. Thus, the efforts of the relevant actors and mechanisms in eliciting pressure to cause states to conform to a reasonable benchmark of the embrace of ethos (of welfarism and several relevant others) that will protect the basic human rights of their citizenry as in the case of Nigeria appears to be a possibly practically workable solution at the minimum; and therefore a veritable recommendation.

As a result of the fact that failure to apply the foregoing recommendation holds sour implications for both the Dominant Class and the subjugated Class alike as seen under the Goodluck Jonathan administration Nigeria (where the lack of the state's provision of a minimum measure of economic value and other social infrastructure central to securing the survival and welfare of the citizenry and by such protecting their human rights, led to the festering of various vices such as violence, terrorism (and the rise of insurgent groups), and all kinds of crime in the Nigerian society that put both the life of members of the subjugated socio-economic class as well as the life and property of the Dominant Class in jeopardy), the state may, with a good deal of veritable pressure from the relevant actors and mechanisms that push for the protection of human rights, ensure that such a minimum measure of welfare is secured. At present, such a minimum of 
welfare appears to be needed to hold sway in Nigeria, and several countries of Africa and of the global South. Given the extreme tendencies of its nature and character, the state may sometimes appear to act in ways that ignore this reality, but it is the role of the relevant actors and mechanisms who play a watchdog and/or regulatory role on the state's activities to elicit veritable pressure on the state long before the consequences of such extreme acts of the state begin to manifest far reaching consequences for all in society.

\section{References:}

1. Adele Jinadu \& U.M.O. Ivowi (eds.) (1982). Human Rights Education in Nigeria. Lagos, Nigeria: S. Agboola International Enterprises.

2. Ake Claude (1981). A Political Economy of Africa. Longman Publishers.

3. Ake Claude (1996). Democracy and Development in Africa. Ibadan, Nigeria: Spectrum Books Limited.

4. Ake Claude (1996). The Political Economy of Crisis and Underdevelopment in Africa. Edited by Julius Ihonvbere. Lagos, Nigeria: JAD Publishers Limited.

5. David Balaam \& Michael Veseth (2001). Introduction to International Political Economy. New Jersey, USA; Prentice Hall.

6. David McLellan (1971). The Thought of Karl Marx. London: The Macmillan Press Ltd. Nigerian Bureau of Statistics www.nigerianstat.gov.ng

7. Fadakinte, M.M. (2013). The Nature and Character of the Nigerian State: Explaining Election Crisis in a Peripheral State. British Journal of Arts and Social Sciences.

8. Fortman Bas De Gaay (2011). The Political Economy of Human Rights: Rights, Realities and Realisation.USA: Routledge Publishers.

9. Goodwin, B. (1982). Using Political Ideas. Chichester: John Wiley and Sons.

10. http://www.nigerianstat.gov.ng

11. John Perkins (2004). The Confession of an Economic Hit Man. USA: Berrett-Koehler Publishers.

12. Knuttila M. and Wendee, K. (eds) (2000). State Theories. London: Zed Books.

13. Marx Karl, Engels Friedrich (1967). The Communist Manifesto. England: Penguin Books Ltd.

14. Madison, G.B. (1998). The Political Economy of Civil Society and Human Rights. USA: Routledge. 
15. Osinbajo Yemi et al. (eds.) (1999). Human Rights, Democracy and Development in Nigeria. Lagos, Nigeria: Florence \& Lambard Ltd. Publishers.

16. Peter Bahr (1999). Human Rights Universality in Practice. Great Britain: Macmillan Press Ltd.

17. Richard Falk, Hilal Elver \& Lisa Hajjar (eds.) (2008). Human Rights Volume I. USA: Routledge Publishers.

18. Solomon O. Akinboye \& M.M Fadikinte (eds.) (2010). Fifty Years of Nationhood? State Society and Politics in Nigeria (1960-2010). Lagos: Concept Publications.

19. Toyin Falola \& Mathew Heaton (2008) A History of Nigeria. UK: Cambridge University Press.

20. Unger, R. M. (1975). Knowledge and Politics. London: The Free Press.

21. Zartman William (1983). The Political Economy of Nigeria. New York, USA: Praeger Publishers. 